\title{
Visualisasi Spasial dan Basis Data Pajak Bumi dan Bangunan (PBB) (Studi Kasus : Desa Bener, Madiun)
} Spatial Visualization and Database of Land and Building Tax (PBB) Spatial Visualization (Case Study: Bener
Village, Madiun)

\author{
Savira Salsabila Firdaus ${ }^{1}$, Yanto Budisusanto*2, Udiana Wahyu Deviantari*3 \\ ${ }^{1,2,3}$ Departemen Teknik Geomatika, FTSPK-ITS, Kampus ITS Sukolilo, Surabaya, 60111, Indonesia \\ *Korespondensi penulis: yanto_b@geodesy.its.ac.id², udiana@geodesy.its.ac.id ${ }^{3}$
}

Diterima: 11082020; Diperbaiki: 31082020; Disetujui: 07092020 Dipublikasi: 21012021

\begin{abstract}
Abstrak: Kabupaten Madiun merupakan salah satu kabupaten di Indonesia yang memiliki kepadatan dengan proporsi 673 penduduk per hektar. Salah satu desa yang ada di Kabupaten Madiun yaitu Desa Bener memiliki kepadatan penduduk yang tinggi, yakni sebesar 1.376 jiwa per $\mathrm{km} 2^{(1)}$. Dengan kepadatan penduduk yang cukup tinggi ini diperlukan adanya kegiatan penarikan PBB secara lebih efisien. Namun dalam kegiatan penarikan PBB masih dilakukan secara manual oleh pihak Kantor Desa Bener ${ }^{(2)}$. Oleh karena itu dibutuhkan suatu daya tampung dalam menghimpun basis data PBB yang sistematis sehingga dapat digunakan dalam penyelenggaraan komputerisasi untuk meningkatkan efektivitas. Sebagai peran yang perlu dilakukan untuk memaknai adanya fungsi pertanahan secara maksimal dari segi spasial, maka dalam penelitian ini memiliki tujuan untuk melakukan visualisasi status atau kondisi PBB terkait dengan kewajiban para Wajib Pajak, terutama untuk memberikan informasi tentang pajak terhutang agar mempermudah dalam pengelolaan pemungutan PBB. Informasi ini diperlukan juga untuk mengetahui objek dengan nilai PBB tinggi harus didahulukan penagihannya.
\end{abstract}

Copyright () 2020 Geoid. All rights reserved.

\begin{abstract}
Madiun Regency is one of the districts in Indonesia with a population density with a population of 673 inhabitants per hectare. One of the villages in Madiun Regency is Bener Village with a high population density of 1,376 people per $\mathrm{km}^{2(1)}$. With a high enough population, a more efficient UN withdrawal activity is needed. However, PBB withdrawal activities are still carried out manually by the Bener Village Office ${ }^{(2)}$. Therefore a capacity is needed in compiling a systematic PBB database so that it can be used in computerization to increase effectiveness. As a role that needs to be done to interpret the existence of a land function maximally from a spatial perspective, this study aims to visualize the status or condition of the PBB related to the obligations of taxpayers, especially to provide information about payable taxes to facilitate the management of PBB collection. The information needed to view objects with PBB value must take precedence for the billing.
\end{abstract}

Kata kunci: PBB, visualisas, basis data

\section{Pendahuluan}

Kabupaten Madiun merupakan salah satu kota di Indonesia yang memiliki kepadatan dengan proporsi 673 penduduk per hektar. Salah satu desa yang ada di Kabupaten Madiun yang memiliki kepadatan penduduk yang tinggi adalah Desa Bener, Kecamatan Saradan yakni sebesar 1.376 jiwa per km2 (BPS, 2018). Hal ini juga ditandai oleh pertumbuhan penduduk yang selalu meningkat ditiap tahunnya. Jumlah penduduk Desa Bener pada tahun 2000 adalah 2.446 jiwa, untuk tahun 2010 jumlah penduduknya 2.412 jiwa dan tahun 2016 jumlah penduduknya mencapai 2.682 jiwa. Dengan kepadatan penduduk yang cukup tinggi ini diperlukan adanya kegiatan penarikan PBB secara lebih efisien. Namun, di Kantor Desa Bener kegiatan penarikan PBB masih dilakukan secara manual sehingga dibutuhkan adanya daya tampung dalam menghimpun basis data PBB yang sistematis dan penyusunan visualisasi secara spasial.

Berdasarkan Pasal 5 Ayat 1 Peraturan Daerah Kota Madiun Nomor 24 Tahun 2011 tentang Pajak Bumi dan Bangunan Perkotaan, yang menjadi dasar pengenaan Pajak Bumi dan Bangunan (PBB) adalah Nilai Jual Objek Pajak (NJOP). NJOP tersebut ditentukan melalui model analisis tertentu berdasarkan ketentuan teknis yang berlaku di Direktorat Jenderal Pajak. Prosedur untuk menentukan NJOP diatur dalam Peraturan Direktur 
Jenderal Pajak Nomor PER-27/PJ/2014 tentang Tata Cara Penetapan Nilai Jual Objek Pajak sebagai Dasar Pengenaan Pajak Bumi dan Bangunan.

Dinas Pendapatan Daerah Kabupaten Madiun telah bekerjasama dengan desa/kelurahan untuk besinergi dalam hal pemungutan PBB di wilayah masing-masing. Seperti halnya di Desa Bener, Kantor Desa Bener melakukan kegiatan yang berkaitan dengan penarikan PBB masih secara manual. Petugas desa masih harus mencocokkan data yang ada di Daftar Himpunan Ketetapan Pajak dan Pembayaran (DHKP) dengan peta bidang tanah analog yang berjumlah sangat banyak. Hal ini tentunya akan memakan waktu yang cukup lama dan tenaga lebih dalam menyelesaikannya atau dengan kata lain lebih tidak efisien. Sehingga penelitiian ini memiliki tujuan untuk melakukan penyusunan basis data dan pembuatan visualisasi terkait hubungan objek dan subjek PBB di Desa Bener guna memberikan kemudahan dalam rangka penarikan pajak dan lebih meningkatkan efektivitas.

\section{Data dan Metode}

Lokasi penelitian berada di Desa Bener, Kecamatan Saradan, Kabupaten Madiun. Secara geografis Desa Bener terletak pada $111^{\circ} 40^{\prime} 25^{\prime \prime} \mathrm{BT}-11^{\circ} 41^{\prime} 40^{\prime \prime} \mathrm{BT}$ dan $7^{\circ} 30^{\prime} 40^{\prime \prime} \mathrm{LS}-7^{\circ} 31^{\prime} 52.5^{\prime \prime} \mathrm{LS}$ dengan luas wilayah \pm 231 Ha. Batas wilayah Desa Bener, Kecamatan Saradan adalah:

$\begin{array}{ll}\text { - } & \text { Sebelah Utara : Desa Duren } \\ \text { - } & \text { Sebelah Timur : Desa Sumbersari } \\ \text { - } & \text { Sebelah Selatan : Desa Sukorejo } \\ & \text { Sebelah Barat } \quad \text { : Desa Kedungmaron }\end{array}$

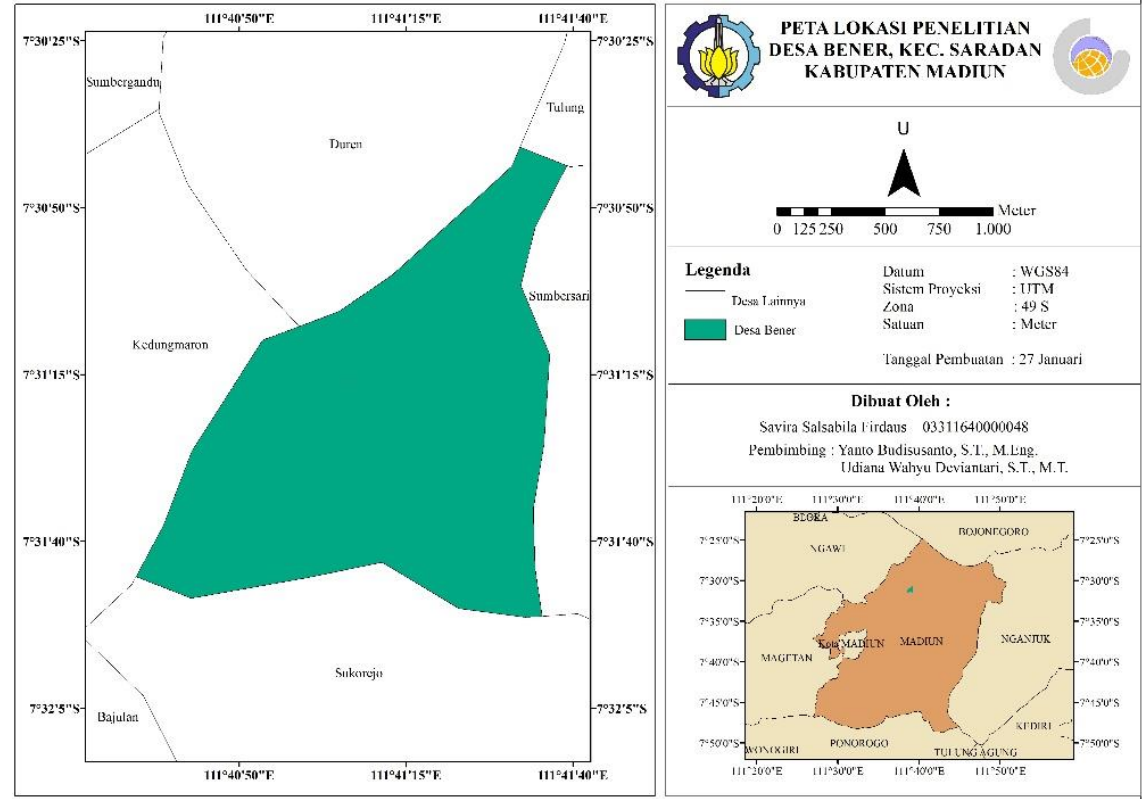

Gambar 1. Lokasi Penelitian (Pengarang, 2020)

Penelitian ini menggunakan data spasial dan data non-spasial. Data spasial yang digunakan berupa Peta Bidang Tanah Digital Desa Bener Tahun 2019 dari Badan Pertanahan Nasional (BPN) Kabupaten Madiun dan Peta Bidang Tanah Analog Desa Bener Tahun 2019 dari Kantor Desa Bener. Sedangkan untuk data non-spasial berupa Salinan buku Daftar Himpunan Ketetapan Pajak dan Pembayaran (DHKP) Desa Bener Tahun 2019. Penelitian ini dilakukan dengan menggunakan perangkat lunak pengolah data spasial dan PostgreSQL.

Dalam penelitian ini dibuatlah 1 basis data dengan nama PBB dan terdiri atas 6 entitas. Entitas tersebut diantaranya adalah desa, dusun, bidang, nama kepemilikan, pembayaran dan status kategori data. Perancangan basis data dibuat guna mendapatkan model basis data yang terstruktur dan saling terintegrasi satu sama lain. Pada perancangan basis data dihasilkan 3 rancangan yaitu: 
- Rancangan Model Konseptual Basis Data

Dalam model ini melakukan identifikasi objek-objek yang terlibat beserta atribut-atribut dan hubungan antar objek. Model konseptual pada penelitian ini ditunjukkan menggunakan diagram Entity Relatinship (ER).

1. Kerangka dan hubungan antara entitas Desa dengan Dusun.

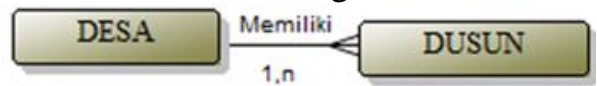

Gambar 2. Diagram ER Desa - Dusun

Kerangka tabel :

- Desa (ID desa sebagai Primary Key, Nama desa)

- Dusun (ID dusun sebagai Primary Key, Nama dusun)

Satu desa boleh memiliki satu atau lebih dusun dan satu atau lebih dusun hanya berada pada satu desa, sehingga direpresentasikan dengan derajat hubungan $1: \mathrm{n}$ (satu dibanding banyak), dengan tingkat partisipasi total pada kedua entitas.

2. Kerangka dan hubungan antara entitas Dusun dengan Bidang.

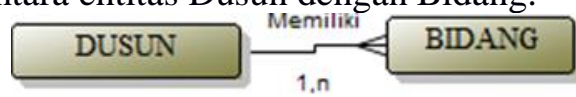

Gambar 3. Diagram ER Dusun - Bidang

Kerangka tabel :

Bidang (ID bidang sebagai Primary Key, NOP, Luas)

Satu dusun boleh memiliki satu atau lebih bidang tanah dan satu atau lebih bidang tanah hanya berada pada satu dusun, sehingga direpresentasikan dengan derajat hubungan 1 : n (satu dibanding banyak), dengan tingkat partisipasi total pada kedua entitas.

3. Kerangka dan hubungan antara entitas Bidang dengan Nama Kepemilikan.

BIDANG $>$ Memiliki ${ }_{n, 1}$ NAMA KEPEMIIIKAN

Gambar 4. Diagram ER Bidang - Nama Kepemilikan

Kerangka tabel : Nama Kepemilikan (ID nama sebagai Primary Key, Nama, Alamat, Total pajak, Tahun Pajak, Tagihan)

Satu atau lebih bidang tanah hanya memiliki satu nama kepemilikan dan satu nama kepemilikan boleh memiliki satu atau lebih bidang tanah, sehingga direpresentasikan dengan derajat hubungan $\mathrm{n}: 1$ (banyakdibanding satu).

4. Kerangka dan hubungan antara entitas Nama Kepemilikan dengan Pembayaran.

\section{NAMA KEPEMIIIKAN}

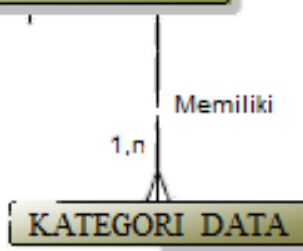

Gambar 5. Diagram ER Nama Kepemilikan - Pembayaran

Kerangka tabel :

Pembayaran (ID pembayaran sebagai Primary Key, Status Pembayaran)

Satu nama kepemilikan boleh memiliki satu atau lebih status kategori data dan satu atau lebih kategori data hanya dimiliki oleh satu nama kepemilikan, sehingga direpresentasikan dengan derajat hubungan $1: \mathrm{n}$ (satu dibanding banyak). 
5. Kerangka dan hubungan antara entitas Nama Kepemilikan dengan Kategori data.

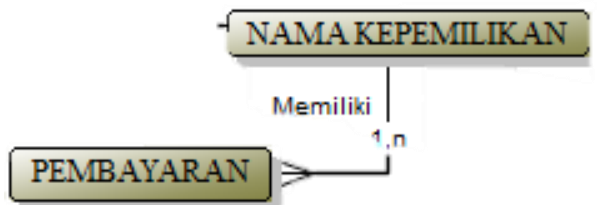

Gambar 6. Diagram ER Nama Kepemilikan - Kategori Data

Kerangka tabel :

Kategori Data (ID kategori sebagai Primary Key, Status Kategori)

Satu nama kepemilikan boleh memiliki satu atau lebih status pembayaran dan satu atau lebih pembayaran hanya dimiliki oleh satu nama kepemilikan, sehingga direpresentasikan dengan derajat hubungan $1: \mathrm{n}$ (satu dibanding banyak).

- Rancangan Model Logikal Basis Data

Pada tahapan ini, jenis SMBD yang dipilih adalah model objek relasional. Kelas beserta atribut - atribut yang telah ditentukan pada model konseptual kemudian diwujudkan ke dalam tabel yang saling berhubungan. Selain itu juga ditentukan elemen kunci baik identitas utama (primary key) maupun identitas tamu (foreign key) dari tiap-tiap tabel.

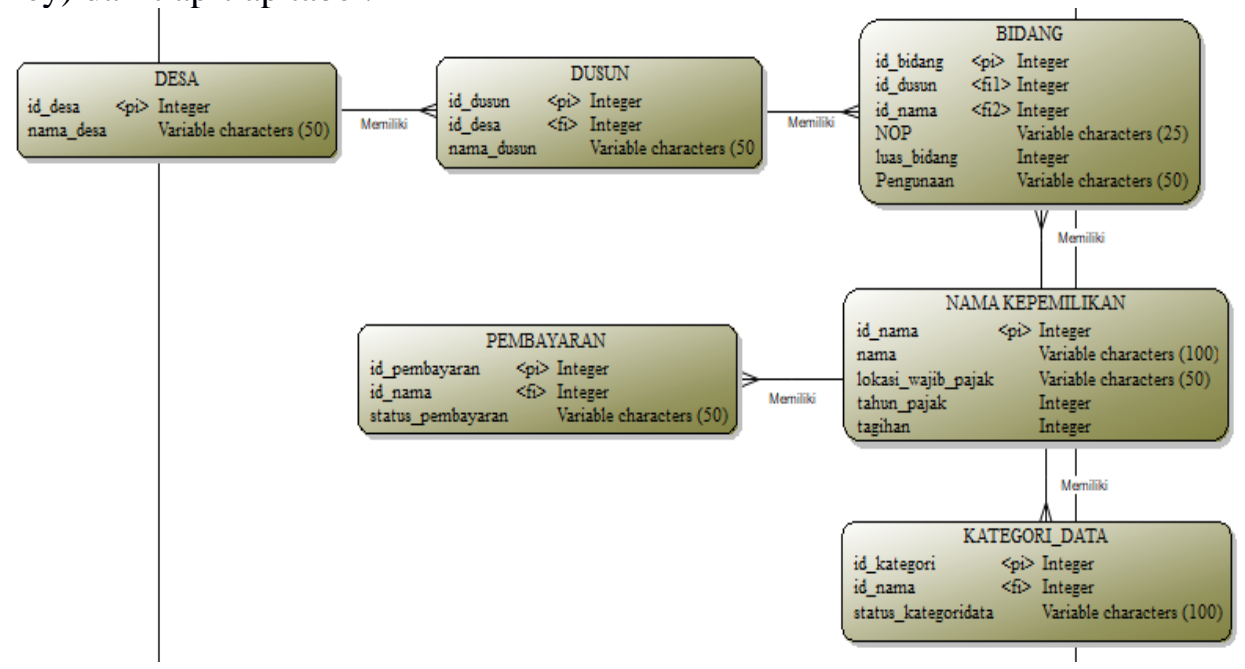

Gambar 7. Model Logikal Basis Data

- Rancangan Model Fisikal Basis Data

Perancangan model fisikal dimaksudkan untuk membuat spesifikasi struktur penyimpanan tabel. Berikut merupakan spesifikasi struktur dari masing-masing berkas data:

Tabel 1. Rancangan Model Fisikal.

\begin{tabular}{clccc}
\hline Table & \multicolumn{1}{c}{ Name } & Data Type & Constrint & Key \\
\hline Desa & id_desa & Integer & Not Null & PK \\
& nama_desa & Varchar (50) & Null & \\
\hline Dusun & id_dusun & Integer & Not Null & PK \\
& id_desa & Integer & Not Null & FK \\
& nama_dusunn & Varchar (50) & Null & \\
\hline Bidang & id_bidang & Integer & Not Null & PK \\
& id_dusun & Integer & Not Null & FK1 \\
& id_nama & Integer & Not Null & FK2 \\
& NOP & Varchar (25) & Null & \\
& luas_bidang & Integer & Null & \\
& Pengunaan & Varchar (50) & Null & \\
\hline
\end{tabular}




\begin{tabular}{clccc}
\hline Nama & id_kategori & Integer & Not Null & FK \\
Kepemilikan & id_nama & Integer & Not Null & PK \\
& nama & Varchar (100) & Null & \\
& lokasi_wajib_pajak & Varchar (50) & Null & \\
& tahun_pajak & Integer & Null & \\
& tagihan & Integer & Null & \\
\hline Pembayaran & id_nama & Integer & Not Null & FK \\
& id_pembayaran & Integer & Not Null & PK \\
& status_pembayaran & Varchar (50) & Null & \\
\hline Kategori Data & id_kategori & Integer & Not Null & PK \\
& status_kategoridata & Varchar (100) & Null & \\
\hline
\end{tabular}

Setelah model rancangan berhasil dibuat langkah selanjutnya adalah melakukan implementasi sistem basis data. Hasil perancangan model logikal dan fisikal kemudian diimplementasikan ke dalam perangkat lunak SMBD yang dipilih (PostgreSQL). Kemudian melakukan uji transaksi basis data untuk memvalidasi data dengan perangkat lunak SIG. Selanjutnya pada tahap penyajian data dilakukan untuk memberikan visualisasi pajak yang harus dibayarkan oleh masing-masing wajib pajak. Visualisasi tersebut berupa peta tematik terkait pemaparan data piutang PBB yang menjadi tanggungjawab dari wajib pajak. Sehingga dapat diketahui potensi peningkatan jumlah PBB yang diterima sebagai bentuk efisiensi dalam pengelolaan PAD untuk tahun 2020.

\section{Hasil dan Pembahasan}

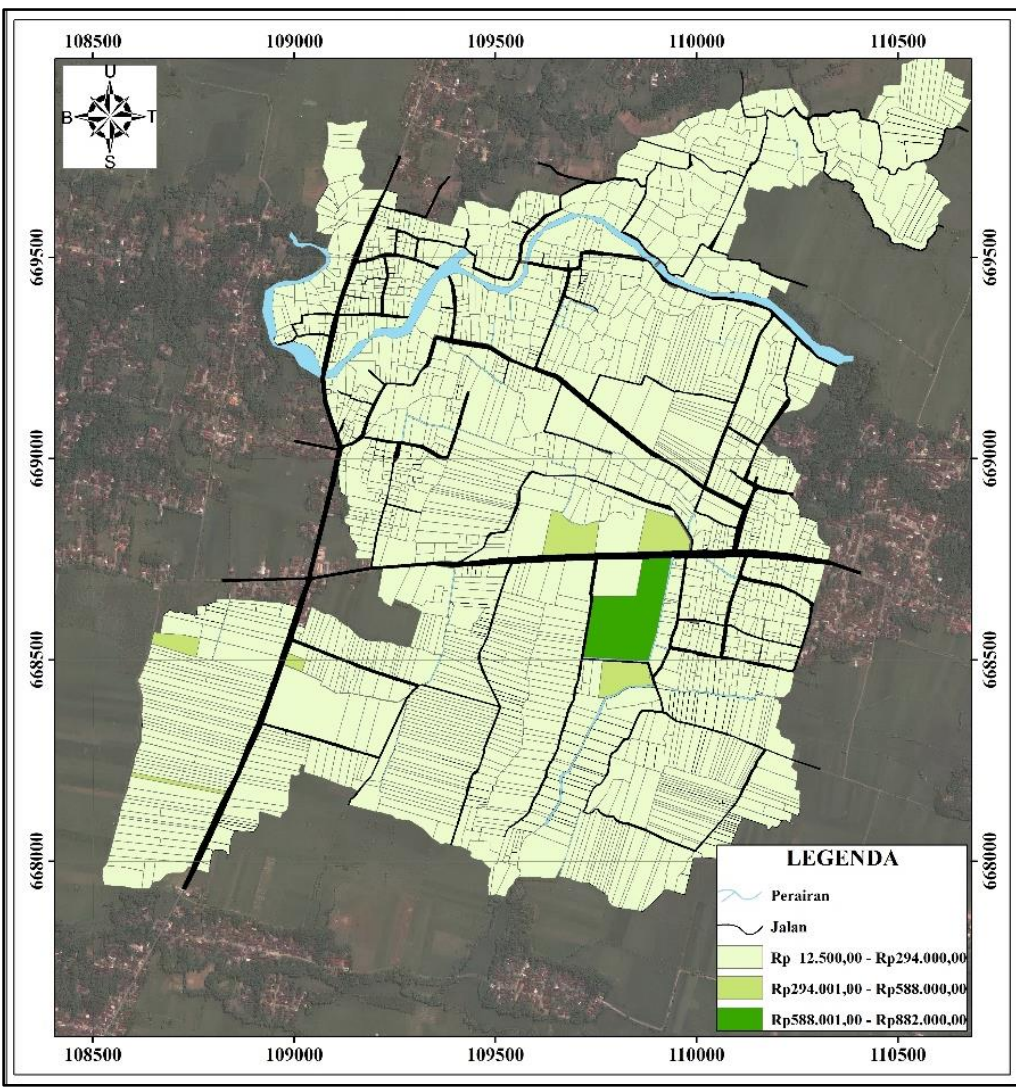

Gambar 8. Hasil Visualisasi Tagihan PBB Desa Bener Menggunakan Perangkat Lunak Pengolah Data Spasial

Pada visualisasi tersebut dibuatlah klasifikasi pada masing-masing total tagihan milik wajib pajk. Rentang nilai yang diambil untuk membuat klasifikasi ini yaitu rentang kecil (Rp12.500,00 - Rp294.000,00) yang ditunjukkan oleh warna hijau muda, rentang sedang (Rp294.001,00 - Rp588.000,00) ditunjukkan oleh warna hijau, rentang besar (Rp588.001,00 - Rp882.000,00) ditunjukkan oleh warna hijau tua. 
Tabel 2. Golongan Klasifikasi.

\begin{tabular}{crr}
\hline Golongan Klasifikasi & Rentang Tagihan & Jumlah Bidang \\
\hline Kecil & Rp12.500,00 - Rp294.000,00 & 1087 bidang \\
Sedang & Rp294.001,00 - Rp588.000,00 & 6 bidang \\
Besar & Rp588.001,00 - Rp882.000,00 & 1 bidang \\
\hline
\end{tabular}

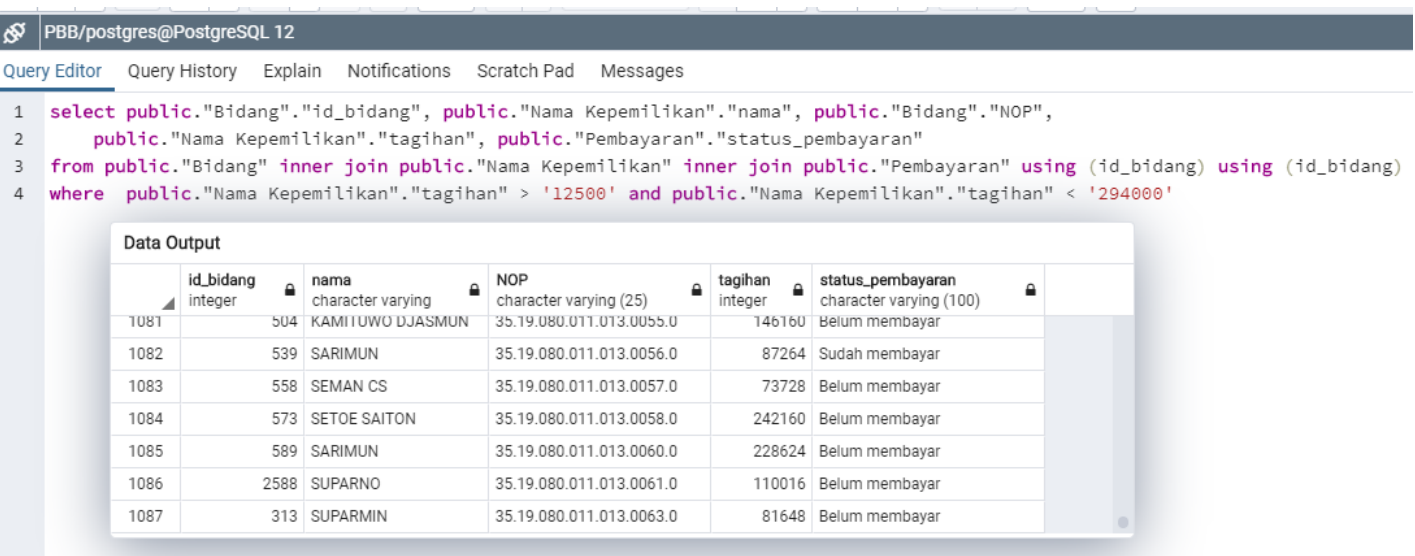

Gambar 9. Query untuk Informasi Jumlah Bidang Tanah dengan Tagihan Rentang Kecil

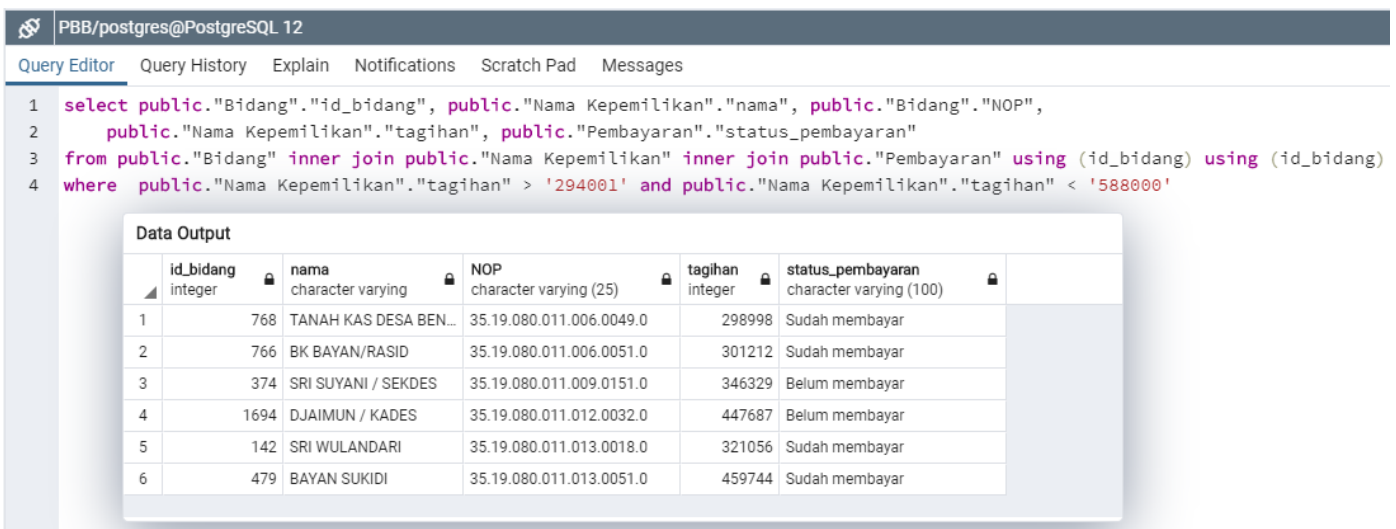

Gambar 10. Query untuk Informasi Jumlah Bidang Tanah dengan Tagihan Rentang Sedang

\section{PBB/postgres@PostgresQL 12}

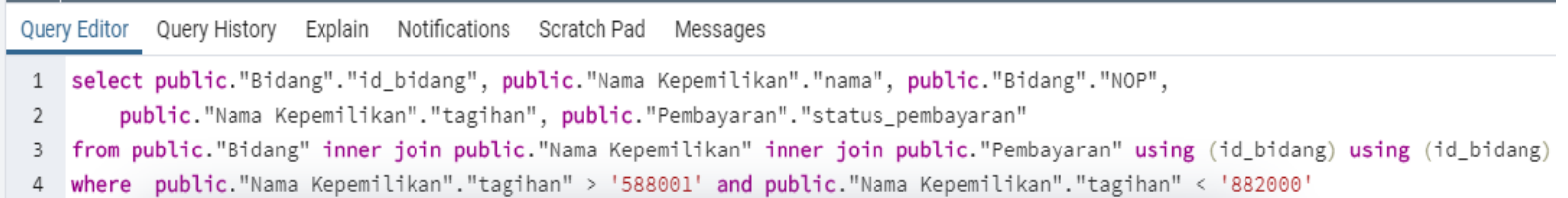

Data Output

\begin{tabular}{|c|c|c|c|c|c|c|c|c|}
\hline ג & $\begin{array}{l}\text { id_bidang } \\
\text { integer }\end{array}$ & e & $\begin{array}{l}\text { nama } \\
\text { character varying }\end{array}$ & a & $\begin{array}{l}\text { NOP } \\
\text { character varying (25) }\end{array}$ & e & $\begin{array}{l}\text { tagihan } \\
\text { integer }\end{array}$ & $\begin{array}{l}\text { status_pembayaran } \\
\text { character varying (100) }\end{array}$ \\
\hline 1 & & 673 & DJAIMUN / KADES & & 35.19 .080 .011 .009 .0148 .0 & & 881172 & Belum membayar \\
\hline
\end{tabular}

Gambar 11. Query untuk Informasi Jumlah Bidang Tanah dengan Tagihan Rentang Tinggi 


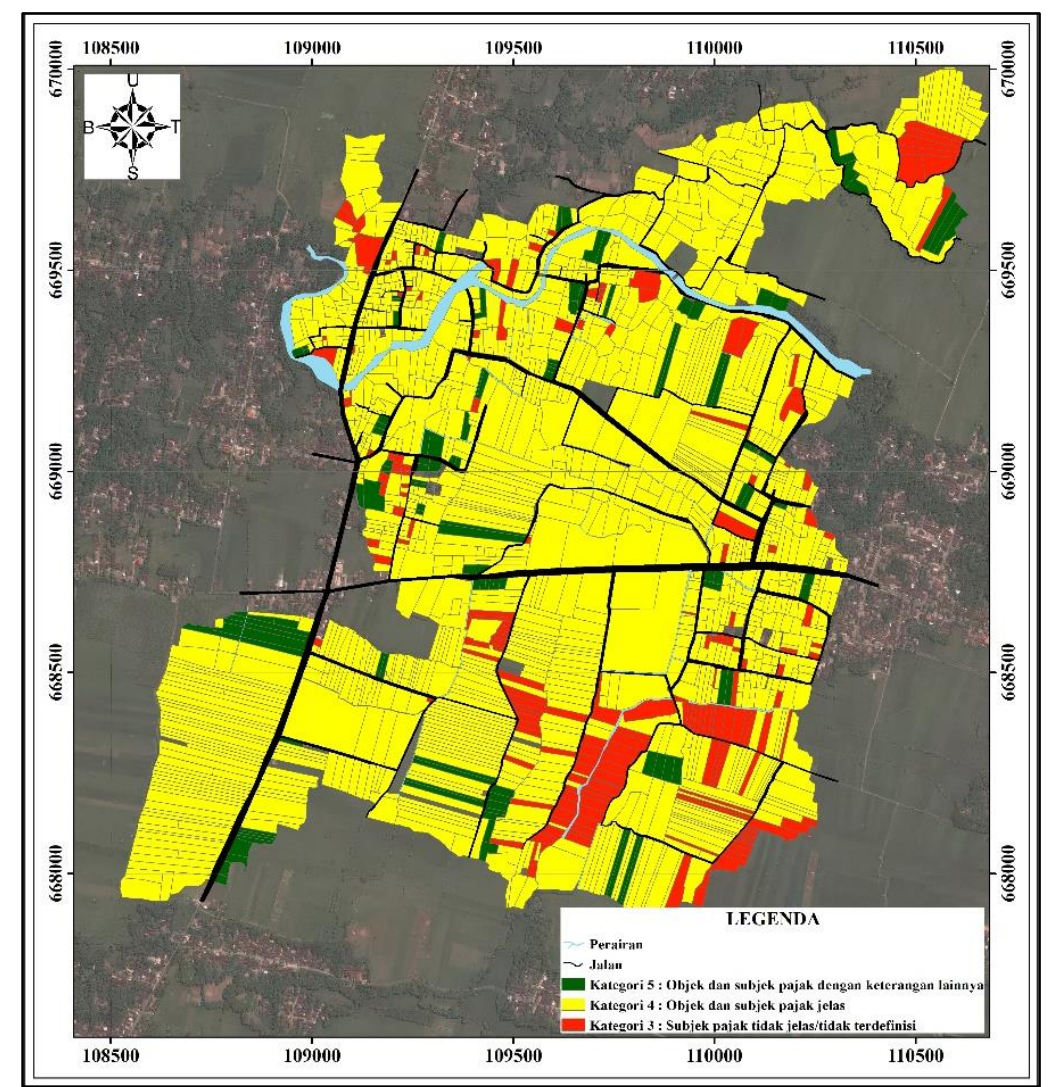

Gambar 12. Hasil Visualisasi Kategori Piutang PBB Desa Bener Menggunakan Perangkat Lunak Pengolah Data Spasial

Berdasarkan pada Surat Edaran Direktur Jenderal Pajak Nomor SE-12/PJ/2012 tentang Pemeliharaan Basis Data Pajak Bumi dan Bangunan. Kategori piutang PBB yang berlaku di Desa Bener sesuai dengan kondisi yang ada yaitu terdapat 3 kategori. Pertama, kategori 3 yang artinya bahwa identitas subjek pajaknya tidak jelas/tidak terdefinisi pada suatu bidang tanah yang terdapat pada 223 bidang tanah. Kategori 4 memiliki arti bahwa subjek pajak dan objek pajak atau bidang tanah dengan identitasnya yang jelas, terdapat pada 1282 bidang tanah. Kategori 5 merupakan kategori dengan identitas subjek pajak dan objek pajak dengan keterangan lain.

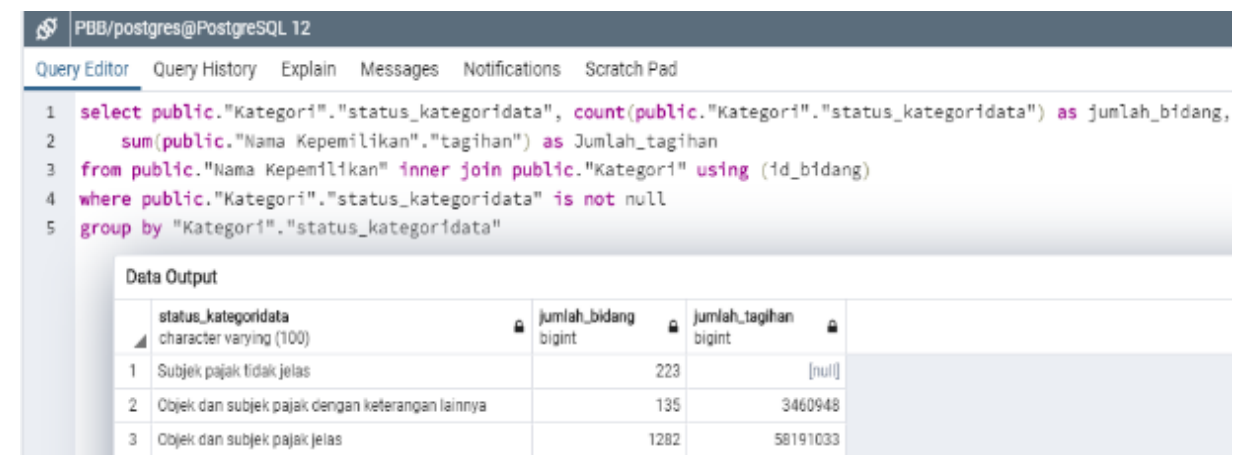

Gambar 13. Query untuk Informasi terkait Kategori Piutang PBB Desa Bener

Dari hasil penerapan query menggunakan PostgreSQL terlihat bahwa berdasarkan status kategori data, terdapat 223 bidang tanah dengan kategori subjek pajaknya tidak jelas/tidak terdefinisi sehingga tidak diketahui total tagihannya, 1282 bidang tanah dengan kategori objek dan subjek pajaknya jelas dan total tagihannya sebesar Rp58.191.033,00; serta 135 bidang tanah dengan kategori objek dan subjek pajaknya dengan keterangan lainnya dan total tagihannya sebesar Rp3.460.948,00. 


\section{Kesimpulan}

Pada penelitian ini dihasilkan suatu model basis data logikal, konseptual dan fisikal untuk menghimpun data piutang PBB di Desa Bener yang memuat informasi terkait kondisi objek dan subjek pajak PBB. Dimana pada kondisi yang ada bahwa terdapat total tagihan dari 1087 bidang tanah yang termasuk dalam total tagihan rentang kecil (Rp12.500,00 - Rp294.000,00), 6 bidang tanah dengan total tagihan pada retang sedang (Rp294.001,00 - Rp588.000,00), dan 1 bidang tanah yang termasuk pada total tagihan rentang tinggi (Rp588.001,00 - Rp882.000,00). Selain itu pada penelitian juga berhasil memuat informasi bahwa terdapat status kategori 3 'subjek pajak tidak jelas/tidak terdefinisi' yang terletak pada 223 bidang tanah; status kategori 4 'objek dan subjek pajak jelas' terdapat pada 1282 bidang tanah dengan total tagihan sebesar Rp58.191.033,00; status kategori 5 'objek dan subjek pajak dengan keterangan lainnya' terdapat pada 135 bidang tanah dengan total tagihan sebesar Rp3.460.948,00.

\section{Ucapan Terimakasih}

Tak lupa penulis mengucapkan terimakasih kepada Tuhan yang Maha Esa telah memberikan kekuatan dalam menyelesaikan penelitian ini. Dan kepada pihak Badan Pertanahan Nasional Kabupaten Madiun dan pihak Kantor Desa Bener yang telah membantu memberikan izin untuk menggunakan data peta bidang tanah Desa Bener.

\section{Daftar Pustaka}

BPS. (2018). Kecamatan Saradan dalam Angka 2018. Madiun: BPS-Statistics of Madiun Regency.

Insukindro. (1994). Penerimaan Pajak. Bandung.

Kementerian Keuangan Republik Indonesia. (2014). Pedoman Umum Pengelolaan Pajak Bumi dan Bangunan Perdesaan dan Perkotaan. Jakarta Pusat: Direktorat Jenderal Perimbangan Keuangan.

Nabilah, B. I. (2016). Pembuatan Basisdata Spasial Nilai Tanah untuk Mengidentifikasi Perubahan Nilai Tanah Pada Tahun 2015-2016 (Studi Kasus : Kecamatan Tuban, Kabupaten Tuban). Jurnal Teknik ITS, Vol. X, No. X.

Nugroho, D. A. (2019). WebSIG Objek Pajak Bumi dan Bangunan untuk Efisiensi Inventaris Pendapatan Daerah (Studi Kasus: Desa Bener, Kecamatan Saradan, Kabupaten Madiun). Jurnal Teknik ITS, Vol. X, No. Y.

Pemerintah Indonesia. (1994). Undang-Undang Republik Indonesia UU No. 12 Tahun 1994 tentang Perubahan Atas Undang-Undang Nomor 12 Tahun 1985 Tentang Pajak Bumi dan Bangunan. Jakarta: Sekretariat Negara.

Prastiwi, D., \& Satyawan, M. (2014). Identifikasi Permasalahan Tunggakan Pajak Bumi dan Bangunan (PBB) di Wilayah Kabupaten Madiun. Jurnal Ilmiah Akuntansi dan Bisnis, Vol. 9 No. 2. 